\title{
The First Total Synthesis of ( \pm )-Methyl Salvianolate A Using a Convergent Strategy
}

\author{
Bo Wang ${ }^{1,+}$, Liping Wang ${ }^{2,+}$, Ying Peng ${ }^{2}$, Yiying Pang ${ }^{2}$, Hesheng Xiao ${ }^{2}$, Xiaoji Wang ${ }^{2, *}$ and \\ Shuangping Huang ${ }^{3,4, *}$ \\ 1 School of Chemistry and Chemical Engineering, Jiangxi Science and Technology Normal University, \\ Nanchang 330013, China; wbo0728@163.com \\ 2 School of Life Science, Jiangxi Science and Technology Normal University, Nanchang 330013, China; \\ wlping92@163.com (L.W.); dapengpeng@163.com (Y.P.); 13667080401@163.com (Y.P.); \\ xiaohes93@163.com (H.X.) \\ 3 School of Pharmacy, Jiangxi Science and Technology Normal University, Nanchang 330013, China \\ 4 College of Biomedical Engineering, Taiyuan University of Technology, Taiyuan 030024, China \\ * Correspondence: 2012207455@tju.edu.cn (X.W.); hsping02@gmail.com (S.H.); Tel.: +86-791-8380-5358 (S.H.) \\ $\dagger$ These two authors contributed equally to this work.
}

Academic Editors: David Díez and María Ángeles Castro

Received: 15 January 2019; Accepted: 7 March 2019; Published: 12 March 2019

\begin{abstract}
Herein, a convergent, practicable and first total synthesis of the natural product, $( \pm)$-methyl salvianolate $\mathrm{A}$, is reported. The key features of the approach are the use of a Horner-Wadsworth-Emmons reaction and the protection of multiple hydroxyls using silyl protecting groups. The employment of the readily removable silyl protecting groups allows the synthesis of $( \pm)$-methyl salvianolate $\mathrm{A}$ and its derivatives on a reasonably large scale.
\end{abstract}

Keywords: methyl salvianolate A; Danshen; total synthesis; Horner-Wadsworth-Emmons reaction; silyl protecting group

\section{Introduction}

Traditional Chinese medicines, which are rich in bioactive natural products, and are widely used in China and Asian countries, play a significant role in the treatment of several diseases. The Chinese herb Danshen from the Chinese Pharmacopoeia has been widely used, for example, to treat cerebro-cardiovascular, gynecologic, and digestive diseases [1]. The significant pharmacological activity may be attributed to the novel biological active components present in Danshen. Phenolic acids are one of the most important types of water-soluble bioactive components. In 1984, $\mathrm{Li}$ and co-workers first isolated the polyphenol acid, (+)-salvianolate A (Figure 1), from the root of Danshen [2]. Salvianolate A showed considerable biological properties, including antioxidant [3-6], cardio- protective [7,8], antiplatelet, and antithrombotic activities [9], as well as reversing the paclitaxel resistance and inhibiting tumor migration and invasion of human breast cancer [10]. These multiple pharmacological effects attracted numerous pharmacological groups to devote their research efforts toward investigating salvianolate A. Twenty three years later, its methyl derivative, $( \pm)$-methyl salvianolate A, was first isolated by the Chen's group [11] from the aqueous extracts of the roots of another species of the Salvia genus, Salvia yunnanensis, and was found to possess pharmacological effects similar to those of salvianolate A, including anti-HIV-1 activity. Due to its similar structure to salvianolate A, $( \pm)$-methyl salvianolate A may also possess the other pharmacological effects than those displayed by salvianolate A. However, no attention has been directed toward the synthesis of $( \pm)$-methyl salvianolate A. Despite the numerous biological studies conducted on salvianolate A, only four total syntheses of salvianolate A [12-15] and one for salvianolate F [16], which possesses a similar 
structure to $( \pm)$-methyl salvianolate $\mathrm{A}$, have been reported to date. Considering the excellent activity and potential pharmacological applications of $( \pm)$-methyl salvianolate A, but its low concentration in Salvia spp. tissues, we became interested in developing an efficient approach towards the synthesis of $( \pm)$-methyl salvianolate A. Herein, we describe the first total synthesis of $( \pm)$-methyl salvianolate A, using a convergent approach [17].
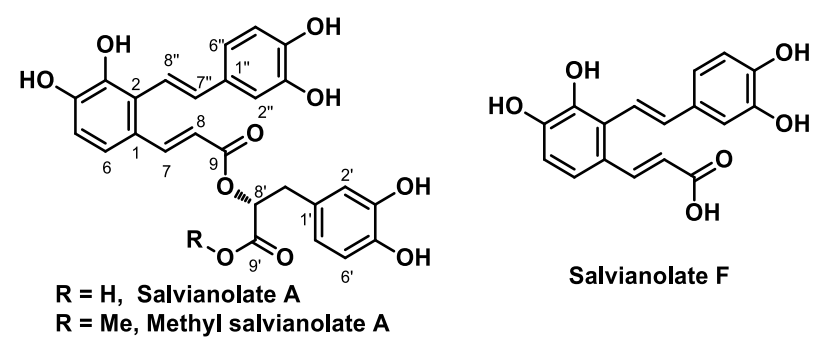

Figure 1. The structures of salvianolate $\mathrm{F}$ and $\mathrm{A}$, and ( \pm )-methyl salvianolate A.

\section{Results}

To the best of our knowledge, most of the published formal syntheses of polyphenol compounds that are structurally similar to $( \pm)$-methyl salvianolate A involve the use of methyl ether protecting groups, which effectively avoids the influence of the phenol groups during the synthesis. However, the use of the methyl ether protecting group results in significant side reactions and low yields during its deprotection, in which a strong Lewis acid, such as $\mathrm{BBr}_{3}$, is usually used. Although an allylic protective group which is more easily removed was employed by Zhang's group, only a moderate yield (41\%) was achieved under the deprotection conditions $\left(\mathrm{Pd}\left(\mathrm{PPh}_{3}\right)_{4}\right.$, morpholine) [15]. As an alternative to using an alkyl group, we looked to install the readily removable tert-butyldimethylsilyl (TBS) group as the protecting group in our total synthesis. Our retrosynthetic analysis of methyl salvianolate A is shown in Scheme 1. ( \pm )-Methyl salvianolate A was disconnected at the C7-C8 bond via a Horner-Wadsworth-Emmons (HWE) reaction to give two Fragments 2 and 3 . We envisaged that fragment 2 could be obtained from fragments 4 and 5 via a Wittig reaction using Cotelle's protocol [16], and that fragment 3 could be prepared from caffeic acid (fragment 6 ).

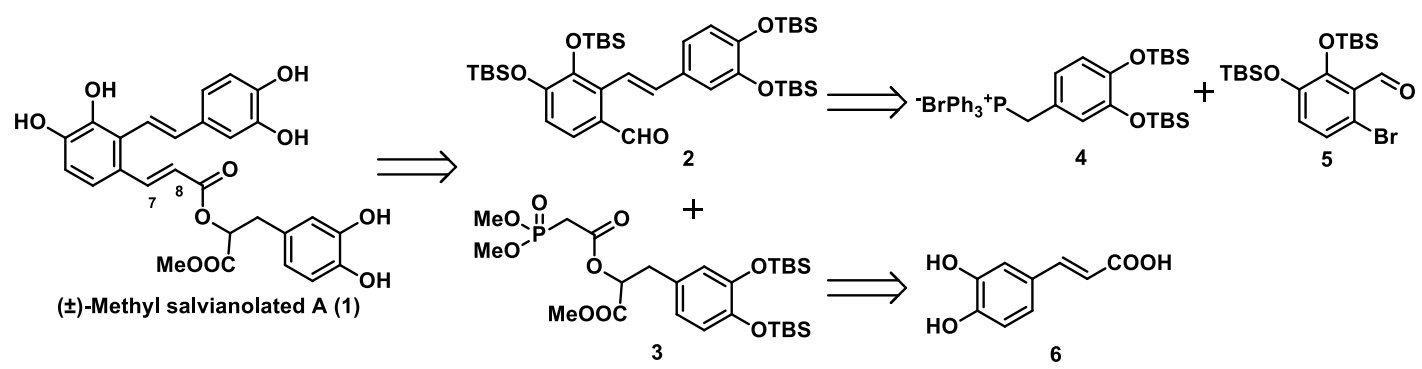

Scheme 1. Retrosynthetic analysis of $( \pm)$-methyl salvianolate A.

As depicted in Scheme 2, our synthesis of $( \pm)$-methyl salvianolate A commenced with the preparation of intermediate 4 from commercially available 4-methylcatechol (7). 4-Methylcatechol was subjected to TBS protection under conventional conditions (TBSCl/imidazole in DMF) to give 8 in an almost quantitative yield. Compound 8 was then subjected to bromination at the benzylic position via a radical process using $N$-bromosuccinimide (NBS) in the presence of $2,2^{\prime}$-azobis- (isobutyronictrile) (AIBN) in $\mathrm{CCl}_{4}$ at $80^{\circ} \mathrm{C}$. Without further purification, the resultant bromide was reacted with triphenyl phosphine in anhydrous $\mathrm{MeCN}$ at $80^{\circ} \mathrm{C}$, followed by washing with toluene to give phosphonium salt 4 in an overall $76 \%$ yield from 8 . Meanwhile, intermediate 5 was prepared from commercially available $o$-vanillin (9). To avoid the influence of the free phenol hydroxyl group, aldehyde 9 first reacted with acetic anhydride to afford 10, which was then converted to monobromide $\mathbf{1 1}$ in the 
presence of potassium bromide and bromine in water (64\% over two steps). The acetyl group in 11 was removed under mild reaction conditions (sodium hydrogen carbonate in $\mathrm{MeOH}$ ) followed by removal of the methyl group using $\mathrm{BBr}_{3}$ at $0{ }^{\circ} \mathrm{C}$ and a second protection step using $\mathrm{TBSCl}$ in the presence of triethylamine and 4-dimethylaminopyridine (DMAP) to achieve intermediate 5 in $69 \%$ yield over three steps.

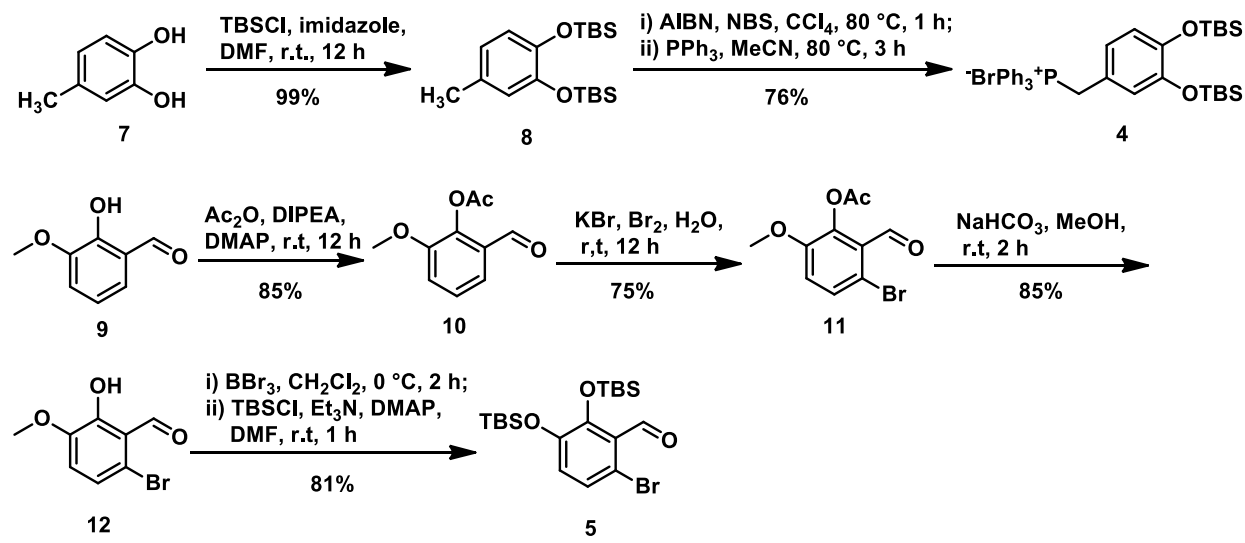

Scheme 2. Synthesis of intermediates 4 and 5.

With intermediates 4 and 5 in hand, we then conducted the Wittig reaction. Treating salt 4 with $\mathrm{n}$-BuLi gave the corresponding ylide that was then reacted with aldehyde 5 at $-78^{\circ} \mathrm{C}$ to afford alkene 13 in $78 \%$ yield with a $E / Z$ ratio of $84: 16$. On exposure to $n$-BuLi at $-78{ }^{\circ} \mathrm{C}$, the resulting anion prepared in situ from the lithium-halogen exchange of alkene 13 was reacted with $N, N$-dimethylformamide at $-20{ }^{\circ} \mathrm{C}$ to give aryl aldehyde 2 in $76 \%$ yield (Scheme 3 ).

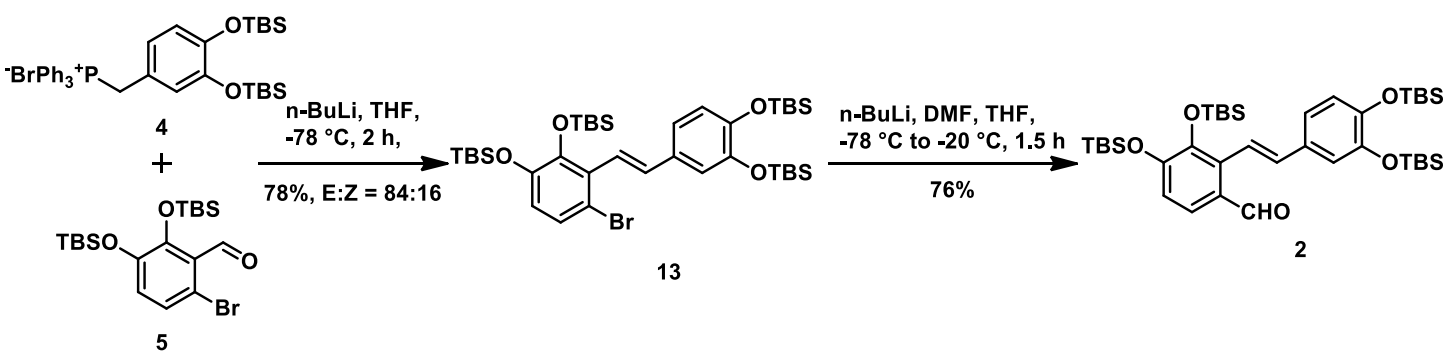

Scheme 3. Synthesis of fragment 2.

For fragment 3, we envisaged an esterification reaction between the commercially available acid 18 and alcohol 17. The latter was synthesized following an established procedure [18] starting from caffeic acid 6, as shown in Scheme 4, which included esterification, TBS protection, dihydroxylation and selective dehydroxylation steps. We obtained intermediate $\mathbf{1 7}$ in an overall 72\% yield from 6. Subsequently, when treated with $N, N^{\prime}$-dicyclohexylcarbodiimide (DCC) and catalytic DMAP in $\mathrm{CH}_{2} \mathrm{Cl}_{2}$ at room temperature, 17 and 18 were assembled into fragment 3 in $90 \%$ yield. 

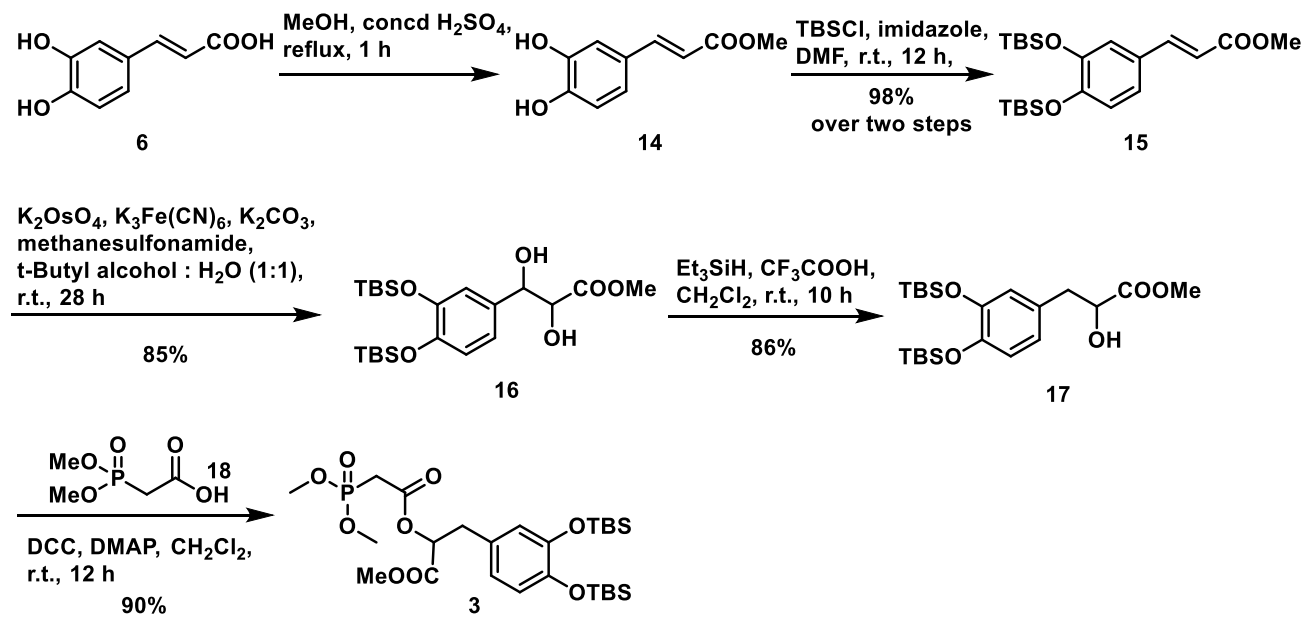

Scheme 4. Synthesis of fragment 3.

At this stage, we needed to connect fragments 2 and 3 to construct the $\alpha, \beta$-unsaturated ester moiety via a HWE reaction. After conducting some experiments in different conditions $(n-\mathrm{BuLi}$, $-78{ }^{\circ} \mathrm{C} ; \mathrm{NaH},-78{ }^{\circ} \mathrm{C} ; \mathrm{NaH}, 0{ }^{\circ} \mathrm{C}$ ), we successfully obtained intermediate 19 in $65 \%$ yield with an $E / \mathrm{Z}$ ratio of $\sim 4: 1$ when performing the $\mathrm{HWE}$ reaction at $0{ }^{\circ} \mathrm{C}$ for $3 \mathrm{~h}$ using $\mathrm{NaH}$ as base (Scheme 5).

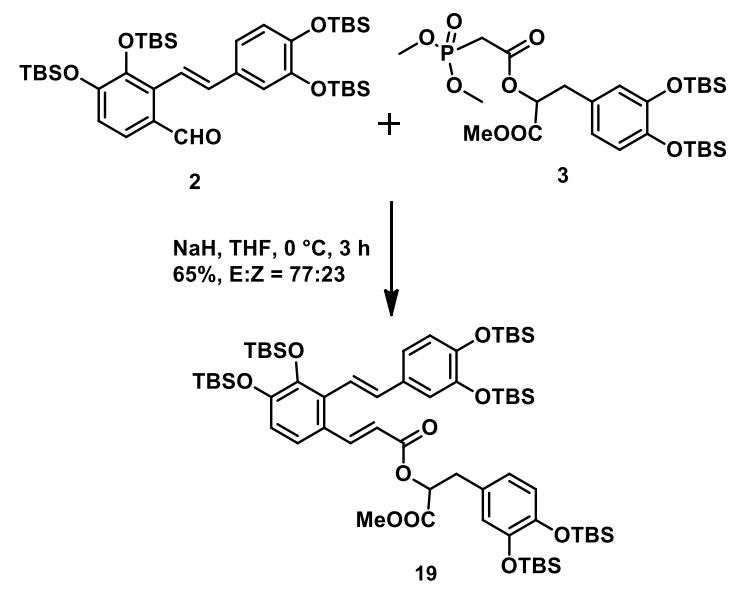

Scheme 5. Assembly of intermediate 19 via HWE reaction.

Finally, with 19 in hand, we turned to conduct the global deprotection step according to our retrosynthetic analysis. However, the deprotection proved surprisingly difficult. It was disappointing to find that the desired product was not obtained when treating 19 with the conventional reagent, tetrabutylammonium fluoride (TBAF). A great deal of TBAF and silicide accompanied $\mathbf{1}$ during the purification step, which hindered the isolation of the target product (Table 1, Entry 1).

A similar phenomenon was observed when conducting the experiment under basic [19-21] or acidic conditions, it gave either no reaction (Entry 2-4,6) or trace amounts of the isolated purified product mixed with a large amount of silicide (Entry $5,7,8$ ). Fortunately, we finally obtained $( \pm$-methyl salvianolate A (1) in excellent yield (92\%) without any silicide after purification using triethylamine trihydrofluoride in anhydrous pyridine (Entry 9) [18,22].

Considering the low efficiency of the demethylation step in the endgame of the formally published total syntheses of the salvianolates, the deprotection of 19 employing the readily removable silyl ether protection group demonstrated that $( \pm)$-methyl salvianolate $\mathrm{A}$ and its derivatives can be prepared on a large scale using our strategy. The physical properties and ${ }^{1} \mathrm{H}$ - and ${ }^{13} \mathrm{C}-\mathrm{NMR}$ spectra of compound 1 obtained using our synthetic route agreed with those reported in the literature [11]. 
Table 1. Completion of the total synthesis of $( \pm)$-methyl salvianolate A.
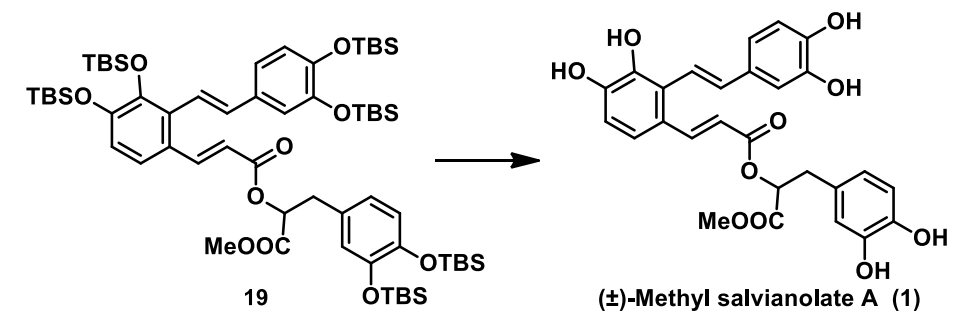

\begin{tabular}{cccc}
\hline Entry & Reagent & Solvent & Yield (\%) \\
\hline 1 & TBAF & THF & $-{ }^{\mathrm{b}}$ \\
2 & $\mathrm{CSA}$ & $\mathrm{MeOH}$ & No reaction \\
3 & $\mathrm{TsOH}$ & $\mathrm{MeOH}$ & No reaction \\
4 & $0.1 \mathrm{M} \mathrm{HCl}$ & $\mathrm{H}_{2} \mathrm{O}$ & No reaction \\
5 & $2.0 \mathrm{M} \mathrm{HCl}$ & $\mathrm{H}_{2} \mathrm{O}$ & $-{ }^{\mathrm{b}}$ \\
6 & $\mathrm{Cs}_{2} \mathrm{CO}_{3}$ & $\mathrm{DMF}-\mathrm{H}_{2} \mathrm{O}(1: 1)$ & No reaction \\
7 & $\mathrm{LiOH}$ & $\mathrm{DMF}$ & $-\mathrm{b}$ \\
8 & $\mathrm{NaOH}$ & $\mathrm{DMF}$ & $-\mathrm{b}$ \\
9 & $\mathrm{Et}_{3} \mathrm{~N} \cdot 3 \mathrm{HF}$ & pyridine & $92 \%$ \\
\hline
\end{tabular}

${ }^{a}$ Isolated yield after silica gel column chromatography. ${ }^{\mathrm{b}}$ Starting material was completely consumed, but only a trace amount of the target product was isolated using silica gel column chromatography with a large amount of 1 not separable from the crude mixture containing silicide.

\section{Experimental Section}

\subsection{General Methods}

All air and water sensitive reactions were carried out under a nitrogen atmosphere with dry solvents under anhydrous conditions, unless otherwise noted. Reactions were monitored by thin-layer chromatography (TLC) carried out on $0.25 \mathrm{~mm}$ silica gel plates (60F-254, Qingdao Ocean Chemical Factory, Qingdao, China) that were analyzed by fluorescence upon $254 \mathrm{~nm}$ irradiation or by staining with anisaldehyde (450 mL of 95\% EtOH, $25 \mathrm{~mL}$ of con. $\mathrm{H}_{2} \mathrm{SO}_{4}(15 \mathrm{~mL})$ of acetic acid, and $25 \mathrm{~mL}$ of anisaldehyde, phosphomolybdic acid (100 mL of $95 \% \mathrm{EtOH}, 10 \mathrm{~g}$ phosphomolybdic acid) and dinitrophenylhydrazine $\left(80 \mathrm{~mL} \mathrm{H} \mathrm{H}_{2} \mathrm{O}, 200 \mathrm{~mL}\right.$ of $95 \% \mathrm{EtOH}, 12 \mathrm{~g}$ dinitrophenylhydrazine and $60 \mathrm{~mL}$ concentrated sulfuric acid). Silica gel (60, particle size $0.040-0.063 \mathrm{~mm}$ ) was used for flash column chromatography. All the chemicals were purchased commercially and used without further purification. Anhydrous THF was distilled from sodium-benzophenone. DMF, $\mathrm{CH}_{3} \mathrm{CN}$ and $\mathrm{CH}_{2} \mathrm{Cl}_{2}$ were distilled from calcium hydride. Yields refer to chromatographically, unless otherwise stated. NMR spectra were recorded on an Avance $400 \mathrm{MHz}$ instrument $\left({ }^{1} \mathrm{H}: 400 \mathrm{MHz},{ }^{13} \mathrm{C}: 100 \mathrm{MHz}\right.$, Bruker Corporation, Karlsruhe, Germany). The following abbreviations were used to explain themultiplicities: $\mathrm{s}=$ singlet, $\mathrm{d}=$ doublet, $\mathrm{m}=$ multiplet. High-resolution mass spectra were obtained from a MALDI-TOF Mass Spectrometer (Applied Biosystems, Carlsbad, CA, USA). IR spectra were obtained using FT-IR Spectrometer (Bruker Vertex 70, Bruker Corporation, Karlsruhe, Germany). NMR and HRMS of compounds 1-5, 8, 10-17, 19 can be found in Supplementary Materials.

\subsection{3,4-Bis(tert-butyldimethylsilyloxy)toluene (8)}

Imidazole (13.7 g, $201.39 \mathrm{mmol})$ and tert-butyldimethylchlorosilane $(18.2 \mathrm{~g}, 120.83 \mathrm{mmol})$ were added to a solution of $7(5.0 \mathrm{~g}, 40.28 \mathrm{mmol})$, which was dissolved in dry DMF $(200 \mathrm{~mL})$, at $0{ }^{\circ} \mathrm{C}$ under a nitrogen atmosphere. The resulting mixture was warmed to room temperature and stirred overnight. The reaction was quenched with brine, extracted with ethyl acetate, and the combined organic layers were washed with brine, dried over anhydrous sodium sulfate, filtered and concentrated in vacuo. The resulting residue was purified by silica gel chromatography to afford compound $8(14.20 \mathrm{~g}, 99 \%)$ as a colorless liquid. ${ }^{1} \mathrm{H}-\mathrm{NMR}\left(\mathrm{CDCl}_{3}\right): \delta 6.72(\mathrm{~d}, J=8.0 \mathrm{~Hz}, 1 \mathrm{H}), 6.65(\mathrm{~s}, 1 \mathrm{H}), 6.61(\mathrm{~d}, J=8.0 \mathrm{~Hz}$, 
1H), $2.24(\mathrm{~s}, 3 \mathrm{H}), 1.01(\mathrm{~s}, 9 \mathrm{H}), 1.00(\mathrm{~s}, 9 \mathrm{H}), 0.21(\mathrm{~s}, 6 \mathrm{H}), 0.20(\mathrm{~s}, 6 \mathrm{H})$; HRMS (TOF-MS): $m / z$ calcd for $\mathrm{C}_{19} \mathrm{H}_{37} \mathrm{O}_{2} \mathrm{Si}_{2}[\mathrm{M}+\mathrm{H}]^{+}$353.2327. Found 353.2327.

\section{3. (3,4-Bis((tert-butyldimethylsilyl)oxy)benzyl)triphenylphosphonium Bromide (4)}

Under a nitrogen atmosphere, $N$-bromosuccinimide $(7.28 \mathrm{~g}, 40.83 \mathrm{mmol})$ and AIBN $(1.1 \mathrm{~g}$, $6.81 \mathrm{mmol})$ were added to a solution of compound $8(12.0 \mathrm{~g}, 34.03 \mathrm{mmol})$ in $\mathrm{CCl}_{4}(70 \mathrm{~mL})$ and the resulting mixture heated at reflux for $1 \mathrm{~h}$. The reaction mixture was filtered and the residue was washed with petroleum ether and concentrated in vacuo to afford the crude product, which was immediately used in the next step without any purification. Triphenylphosphine (13.38 g, $51.04 \mathrm{mmol})$ was then added to the crude product solution in dry $\mathrm{MeCN}(70 \mathrm{~mL})$ and the resulting mixture was heated under reflux for $3 \mathrm{~h}$. The reaction mixture was cooled to room temperature and concentrated in vacuo. Toluene was added to the crude product and the resulting suspension filtered to give phosphonium salt 4 (17.94 g, 76\% over two steps) as a pale yellow solid. ${ }^{1} \mathrm{H}-\mathrm{NMR}\left(\mathrm{CDCl}_{3}\right): 87.79-7.62$ $(\mathrm{m}, 15 \mathrm{H}), 6.61(\mathrm{~s}, 2 \mathrm{H}), 6.47(\mathrm{~s}, 1 \mathrm{H}), 5.16(\mathrm{~d}, J=13.6 \mathrm{~Hz}, 2 \mathrm{H}), 0.93(\mathrm{~s}, 9 \mathrm{H}), 0.84(\mathrm{~s}, 9 \mathrm{H}), 0.15(\mathrm{~s}, 6 \mathrm{H}),-0.05$ (s, 6H); HRMS (TOF-MS): $m / z$ calcd for $\mathrm{C}_{37} \mathrm{H}_{50} \mathrm{O}_{2} \mathrm{Si}_{2} \mathrm{P}$ [M-Br- $]^{+}$613.3081. Found 613.3082.

\subsection{2-Formyl-6-methoxyphenyl Acetate (10)}

A catalytic quantity of 4-dimethylaminopyridine $(0.96 \mathrm{~g}, 7.89 \mathrm{mmol})$ and acetic anhydride $(8.07 \mathrm{~mL}, 85.44 \mathrm{mmol})$ were added to an 0 -vanillin $(9,10.01 \mathrm{~g}, 65.72 \mathrm{mmol})$ solution in $\mathrm{N}, \mathrm{N}$-diisopropylethylamine $(33 \mathrm{~mL})$ at $0{ }^{\circ} \mathrm{C}$ under a nitrogen atmosphere. The solution was allowed to warm to room temperature and stirred overnight. After compound 9 was completely consumed, hydrochloric acid $(2 \mathrm{M}, 100 \mathrm{~mL})$ was added. The resulting mixture was stirred for another $10 \mathrm{~min}$ and then extracted with dichloromethane $(100 \mathrm{~mL} \times 3)$. The combined organic layers were concentrated in vacuo to afford a crude yellow solid, which was recrystallized from ethanol to give compound 10 $(10.85 \mathrm{~g}, 85 \%)$ as a yellow solid. ${ }^{1} \mathrm{H}-\mathrm{NMR}\left(\mathrm{CDCl}_{3}\right): \delta 10.12(\mathrm{~s}, 1 \mathrm{H}), 7.43(\mathrm{~d}, J=7.6 \mathrm{~Hz}, 1 \mathrm{H}), 7.31(\mathrm{t}$, $J=8.4 \mathrm{~Hz}, 1 \mathrm{H}), 7.20(\mathrm{~d}, J=8.4 \mathrm{~Hz}, 1 \mathrm{H}), 3.85(\mathrm{~s}, 3 \mathrm{H}), 2.39(\mathrm{~s}, 3 \mathrm{H}) . ;{ }^{13} \mathrm{C}-\mathrm{NMR}\left(100 \mathrm{MHz}, \mathrm{CDCl}_{3}\right): \delta 188.7$, $168.7,151.8,141.5,129.2,126.8,121.2,117.9,56.3,20.4$.

\subsection{3-Bromo-2-formyl-6-methoxyphenyl Acetate (11)}

Bromine $(3.73 \mathrm{~mL}, 72.64 \mathrm{mmol})$ was added to a potassium bromide $(21.47 \mathrm{~g}, 180.48 \mathrm{mmol})$ solution in $\mathrm{H}_{2} \mathrm{O}(133 \mathrm{~mL})$. Aldehyde $10(10.85 \mathrm{~g}, 55.88 \mathrm{mmol})$ was added to the resulting dark red solution and stirred overnight. The reaction was monitored by TLC until 10 was completely consumed. The reaction mixture was extracted with ethyl acetate, the layers separated and the organic layer concentrated in vacuo. The resulting residue was recrystallized from ethyl acetate-hexane to give compound 11 $(11.44 \mathrm{~g}, 75 \%)$ as yellow crystals. ${ }^{1} \mathrm{H}-\mathrm{NMR}\left(\mathrm{CDCl}_{3}\right): \delta 10.35(\mathrm{~s}, 1 \mathrm{H}), 7.59(\mathrm{~d}, J=8.8 \mathrm{~Hz}, 1 \mathrm{H}), 7.14(\mathrm{~d}$, $J=8.8 \mathrm{~Hz}, 1 \mathrm{H}), 3.94(\mathrm{~s}, 3 \mathrm{H}), 2.47(\mathrm{~s}, 3 \mathrm{H}) ;{ }^{13} \mathrm{C}-\mathrm{NMR}\left(\mathrm{CDCl}_{3}\right): \delta 190.3,168.7,151.9,140.4,131.5,126.6$, $117.8,116.3,56.4,20.5$.

\subsection{6-Bromo-2-hydroxy-3-methoxybenzaldehyde (12)}

Sodium bicarbonate $(4.93 \mathrm{~g}, 58.64 \mathrm{mmol})$ was added to a solution of aldehyde 11 (11.44 g, $41.89 \mathrm{mmol}$ ) solution in a mixture of methanol and water $(v / v=2: 1,84 \mathrm{~mL})$. The resulting turbid yellow solution was stirred for $2 \mathrm{~h}$ at room temperature. Hydrochloric acid $(1 \mathrm{M})$ was then added to adjust the $\mathrm{pH}$ to $6-7$ and the mixture extracted with ethyl acetate $(100 \mathrm{~mL} \times 3)$. The combined organic layers were concentrated in vacuo and the crude yellow solid recrystallized from ethyl acetate/hexane to give compound $12(8.23 \mathrm{~g}, 85 \%)$ as yellow acicular crystals. ${ }^{1} \mathrm{H}-\mathrm{NMR}\left(\mathrm{CDCl}_{3}\right): \delta 12.26(\mathrm{~s}, 1 \mathrm{H}), 10.27$ $(\mathrm{s}, 1 \mathrm{H}), 7.07(\mathrm{~d}, J=8.4 \mathrm{~Hz}, 1 \mathrm{H}), 6.90(\mathrm{~d}, J=8.4 \mathrm{~Hz}, 1 \mathrm{H}), 3.88(\mathrm{~s}, 3 \mathrm{H}) ;{ }^{13} \mathrm{C}-\mathrm{NMR}\left(\mathrm{CDCl}_{3}\right): \delta 198.3,154.4$, $148.3,123.3,118.2,117.1,116.3,56.3$. 


\subsection{6-Bromo-2,3-bis((tert-butyldimethylsilyl)oxy)benzaldehyde (5)}

Boron tribromide $(13.47 \mathrm{~mL}, 142.48 \mathrm{mmol})$ in $\mathrm{CH}_{2} \mathrm{Cl}_{2}(60 \mathrm{~mL})$ was added dropwise to a solution of compound $12(8.23 \mathrm{~g}, 35.62 \mathrm{mmol})$ in dry $\mathrm{CH}_{2} \mathrm{Cl}_{2}(120 \mathrm{~mL})$ at $0{ }^{\circ} \mathrm{C}$ under a nitrogen atmosphere. The resulting mixture was then stirred for $2 \mathrm{~h}$. Ice-water $(100 \mathrm{~mL})$ was added slowly to quench the reaction, the layers separated and the organic layer concentrated in vacuo. The residue was washed with water, filtered and the resulting yellow filter cake dried at $40{ }^{\circ} \mathrm{C}$ to give the crude product as a yellow solid, which was used in the next step without any further purification. $\mathrm{Et}_{3} \mathrm{~N}(16.50 \mathrm{~mL}$, $118.37 \mathrm{mmol})$, DMAP $(0.826 \mathrm{~g}, 6.76 \mathrm{mmol})$ and tert-butyldimethylchlorosilane $(15.29 \mathrm{~g}, 101.46 \mathrm{mmol})$ were added to the above crude solid $(7.34 \mathrm{~g}, 33.82 \mathrm{mmol})$ in dry DMF $(307 \mathrm{~mL})$ at $0{ }^{\circ} \mathrm{C}$ under a nitrogen atmosphere. The resulting solution was stirred for $1 \mathrm{~h}$ at $0{ }^{\circ} \mathrm{C}$. The reaction was quenched with brine, extracted with ethyl acetate $(200 \mathrm{~mL} \times 3)$ and the combined organic layers concentrated in vacuo. The resulting residue was purified by silica gel chromatography to give intermediate $5(12.85 \mathrm{~g}, 81 \%$ over two steps). ${ }^{1} \mathrm{H}-\mathrm{NMR}\left(\mathrm{CDCl}_{3}\right): \delta 10.29(\mathrm{~s}, 1 \mathrm{H}), 7.11(\mathrm{~d}, J=8.4 \mathrm{~Hz}, 1 \mathrm{H}), 6.87(\mathrm{~d}, J=8.8 \mathrm{~Hz}, 1 \mathrm{H})$, 1.00 (s, 9H), 0.96 (s, 9H), 0.23 (s, 6H), $0.12(\mathrm{~s}, 6 \mathrm{H}) ;{ }^{13} \mathrm{C}-\mathrm{NMR}\left(\mathrm{CDCl}_{3}\right): \delta$ 189.4, 149.3, 146.9, 127.0, 126.0, 124.6, 112.8, 25.1, 25.0, 17.7, 17.5, -4.7, -4.8; HRMS (TOF-MS): $m / z$ calcd for $\mathrm{C}_{19} \mathrm{H}_{34} \mathrm{BrO}_{3} \mathrm{Si}_{2}[\mathrm{M}+\mathrm{H}]^{+}$ 445.1224. Found 445.1230.

\section{8. (E)-6-Bromo-2,3,3',4'-tetrakis(tert-butyldimethylsilyloxy)stilbene (13)}

$n$-BuLi (10.3 mL, 2.5 M in hexane, $25.81 \mathrm{mmol}$ ) was slowly added to a suspension of phosphonium salt $4(19.47 \mathrm{~g}, 28.06 \mathrm{mmol})$ in dry THF $(100 \mathrm{~mL})$ at $-78{ }^{\circ} \mathrm{C}$ under a nitrogen atmosphere and the resulting mixture was stirred for $30 \mathrm{~min}$ at $-78^{\circ} \mathrm{C}$. Aldehyde $5(5.0 \mathrm{~g}, 11.22 \mathrm{mmol})$ dissolved in dry THF $(40 \mathrm{~mL})$ was added dropwise to the reaction mixture and the resulting solution stirred for another $1 \mathrm{~h}$ at $-78^{\circ} \mathrm{C}$. The reaction was quenched with a saturated aqueous solution of ammonium chloride. The mixture was extracted with ethyl acetate $(100 \mathrm{~mL} \times 3)$ and the combined organic layers washed with brine, dried over anhydrous sodium sulfate, filtered and concentrated in vacuo. The resulting residue was purified by silica gel chromatography to give compound $13(17.08 \mathrm{~g}, 78 \%, E: Z=84: 16)$ as a colorless oil. ${ }^{1} \mathrm{H}-\mathrm{NMR}$ $\left(\mathrm{CDCl}_{3}\right): \delta 7.11(\mathrm{~d}, J=8.4 \mathrm{~Hz}, 1 \mathrm{H}), 7.02(\mathrm{~d}, J=8.8 \mathrm{~Hz}, 1 \mathrm{H}), 7.00(\mathrm{~d}, J=17.2 \mathrm{~Hz}, 1 \mathrm{H}), 6.94(\mathrm{~s}, 1 \mathrm{H}), 6.85(\mathrm{~d}$, $J=16.8 \mathrm{~Hz}, 1 \mathrm{H}), 6.84(\mathrm{~d}, J=8.4 \mathrm{~Hz}, 1 \mathrm{H}), 6.66(\mathrm{~d}, J=8.4 \mathrm{~Hz}, 1 \mathrm{H}), 1.04(\mathrm{~s}, 18 \mathrm{H}), 1.02(\mathrm{~s}, 9 \mathrm{H}), 0.95(\mathrm{~s}, 9 \mathrm{H})$, $0.28(\mathrm{~s}, 6 \mathrm{H}), 0.26(\mathrm{~s}, 12 \mathrm{H}), 0.09(\mathrm{~s}, 6 \mathrm{H}) . ;{ }^{13} \mathrm{C}-\mathrm{NMR}\left(\mathrm{CDCl}_{3}\right): \delta 147.3,146.9,146.8,145.6,135.2,131.8,131.2$, 125.4, 123.5, 121.0, 120.0, 119.1, 115.5, 26.2, 26.2, 26.0, 25.9, 18.8, 18.5, 18.5, 18.3, -3.5, -3.6, -4.0 -4.1; HRMS (TOF-MS): $m / z$ calcd for $\mathrm{C}_{36} \mathrm{H}_{68} \mathrm{BrO}_{4} \mathrm{Si}_{4}[\mathrm{M}+\mathrm{H}]^{+}$779.3373. Found 779.3378.

\section{9. (E)-2-(3,4-Bis((tert-butyldimethylsilyl)oxy)styryl)-3,4-bis((tert-butyldimethyl-silyl)oxy)benzaldehyde (2)}

n-BuLi (6.7 mL, 2.5 M in hexane, $16.82 \mathrm{mmol})$ was added to a solution of compound 13 (6.56 $\mathrm{g}$, $8.41 \mathrm{mmol})$ in dry $\mathrm{THF}(40 \mathrm{~mL})$ at $-78^{\circ} \mathrm{C}$ under a nitrogen atmosphere. After the reaction mixture was stirred for $30 \mathrm{~min}$ at $-78{ }^{\circ} \mathrm{C}$, dry $\mathrm{N}, \mathrm{N}$-dimethylformamide $(6.50 \mathrm{~mL}, 84.08 \mathrm{mmol})$ in dry THF (10 mL) was slowly added to the mixture and stirred for another $30 \mathrm{~min}$ at $-78^{\circ} \mathrm{C}$ until 13 was completely consumed. The reaction was quenched with a saturated aqueous solution of ammonium chloride and hydrochloric acid ( $1 \mathrm{M}$ ) added to adjust the $\mathrm{pH}$ to 1 . The mixture was extracted with ethyl acetate $(50 \mathrm{~mL} \times 3)$ and the combined organic layers dried over anhydrous $\mathrm{Na}_{2} \mathrm{SO}_{4}$, filtered and concentrated in vacuo. The resulting residue was purified by silica gel chromatography to give compound 2 (4.66 $\mathrm{g}$, $76 \%)$ as a yellow oil. ${ }^{1} \mathrm{H}-\mathrm{NMR}\left(\mathrm{CDCl}_{3}\right): \delta 10.08(\mathrm{~s}, 1 \mathrm{H}), 7.56(\mathrm{~d}, J=8.4 \mathrm{~Hz}, 1 \mathrm{H}), 7.18(\mathrm{~d}, J=16.4 \mathrm{~Hz}, 1 \mathrm{H})$, $7.02(\mathrm{~s}, 1 \mathrm{H}), 6.99(\mathrm{~d}, J=8.4 \mathrm{~Hz}, 1 \mathrm{H}), 6.91(\mathrm{~d}, J=8.4 \mathrm{~Hz}, 1 \mathrm{H}), 6.85(\mathrm{~d}, J=8.0 \mathrm{~Hz}, 1 \mathrm{H}), 6.46(\mathrm{~d}, J=16.4 \mathrm{~Hz}$, $1 \mathrm{H}), 1.03(\mathrm{~s}, 9 \mathrm{H}), 1.03(\mathrm{~s}, 9 \mathrm{H}), 1.02(\mathrm{~s}, 9 \mathrm{H}), 0.99(\mathrm{~s}, 9 \mathrm{H}), 0.31(\mathrm{~s}, 6 \mathrm{H}), 0.26(\mathrm{~s}, 6 \mathrm{H}), 0.25(\mathrm{~s}, 6 \mathrm{H}), 0.13(\mathrm{~s}, 6 \mathrm{H})$.; ${ }^{13} \mathrm{C}-\mathrm{NMR}\left(\mathrm{CDCl}_{3}\right): \delta 192.6,152.9,148.4,147.9,145.5,139.4,137.3,131.4,130.2,124.0,122.0,121.4,120.5$, $120.4,120.2,27.1,27.0,26.9,19.8,19.4,19.4,19.3,-2.4,-2.6,-3.1,-3.1$; HRMS (TOF-MS): $\mathrm{m} / \mathrm{z}$ calcd for $\mathrm{C}_{39} \mathrm{H}_{69} \mathrm{O}_{5} \mathrm{Si}_{4}[\mathrm{M}+\mathrm{H}]^{+}$729.4217. Found 729.4218 . 


\subsection{0. (E)-methyl 3-(3,4-dihydroxyphenyl)acrylate (14)}

Concentrated sulfuric acid $(4 \mathrm{~mL})$ was slowly added to a solution of caffeic acid $(6,2.0 \mathrm{~g}$, $11.10 \mathrm{mmol})$ in methanol $(140 \mathrm{~mL})$. The resulting mixture was heated at reflux for $1 \mathrm{~h}$. Aqueous $\mathrm{NaOH}(1 \mathrm{M})$ was added to quench the reaction and adjust the $\mathrm{pH}$ to 6-7. The aqueous phase was extracted with $\mathrm{CH}_{2} \mathrm{Cl}_{2}(100 \mathrm{~mL} \times 3)$. The combined organic layers were washed with brine, dried over anhydrous sodium sulfate, filtered and concentrated in vacuo. The resulting crude product ( $2.15 \mathrm{~g})$ was used in the next step without any further purification. ${ }^{1} \mathrm{H}-\mathrm{NMR}\left(\mathrm{CD}_{3} \mathrm{OD}\right): \delta 7.51(\mathrm{~d}, J=16.0 \mathrm{~Hz}$, $1 \mathrm{H}), 7.03(\mathrm{~s}, 1 \mathrm{H}), 6.90(\mathrm{~d}, J=8.0 \mathrm{~Hz}, 1 \mathrm{H}), 6.77(\mathrm{~d}, J=8.4 \mathrm{~Hz}, 1 \mathrm{H}), 6.22(\mathrm{~d}, J=16.0 \mathrm{~Hz}, 1 \mathrm{H}), 4.98$ (br s, 2H), 3.71 (s, 3H).; ${ }^{13} \mathrm{C}-\mathrm{NMR}\left(\mathrm{CD}_{3} \mathrm{OD}\right): \delta 167.5,147.1,144.6,144.4,125.5,120.7,114.2,113.0,112.6,49.8$; HRMS (TOF-MS): $m / z$ calcd for $\mathrm{C}_{10} \mathrm{H}_{11} \mathrm{O}_{4}[\mathrm{M}+\mathrm{H}]^{+}$195.0652. Found 195.0658.

\subsection{1. (E)-methyl 3-(3,4-bis((tert-butyldimethylsilyl)oxy)phenyl)acrylate (15)}

Imidazole $(5.28 \mathrm{~g}, 77.51 \mathrm{mmol})$ and tert-butyldimethylchlorosilane $(5.0 \mathrm{~g}, 33.22 \mathrm{mmol})$ were added to the crude compound $14(2.15 \mathrm{~g}, 11.07 \mathrm{mmol})$ dissolved in dry DMF $(60 \mathrm{~mL})$ at $0{ }^{\circ} \mathrm{C}$. The reaction mixture was allowed to warm up to room temperature and stirred overnight. The reaction was quenched with brine, extracted with ethyl acetate $(100 \mathrm{~mL} \times 3)$ and the combined organic layers were dried over anhydrous sodium sulfate, filtered and concentrated in vacuo. The resulting residue was purified by silica gel chromatography to afford compound $15(4.74 \mathrm{~g}, 98 \%)$ as a white solid. ${ }^{1} \mathrm{H}-\mathrm{NMR}$ $\left(\mathrm{CDCl}_{3}\right): \delta 7.56(\mathrm{~d}, J=16.0 \mathrm{~Hz}, 1 \mathrm{H}), 7.01(\mathrm{~s}, 1 \mathrm{H}), 6.99(\mathrm{~d}, J=5.6 \mathrm{~Hz}, 1 \mathrm{H}), 6.81(\mathrm{~d}, J=8.4 \mathrm{~Hz}, 1 \mathrm{H}), 6.23(\mathrm{~d}$, $J=16.0 \mathrm{~Hz}, 1 \mathrm{H}), 3.77(\mathrm{~s}, 3 \mathrm{H}), 0.98(\mathrm{~s}, 9 \mathrm{H}), 0.97(\mathrm{~s}, 9 \mathrm{H}), 0.20(\mathrm{~s}, 6 \mathrm{H}), 0.20(\mathrm{~s}, 6 \mathrm{H}) . ;{ }^{13} \mathrm{C}-\mathrm{NMR}\left(\mathrm{CDCl}_{3}\right)$ : $\delta 167.7,149.4,147.2,144.8,128.0,122.2,121.1,120.4,115.4,51.5,25.9,25.9,18.5,18.4,-4.1,-4.1$; HRMS (TOF-MS): $m / z$ calcd for $\mathrm{C}_{22} \mathrm{H}_{39} \mathrm{O}_{4} \mathrm{Si}_{2}[\mathrm{M}+\mathrm{H}]^{+}$423.2381. Found 423.2376.

\subsection{Methyl 3-(3,4-bis((tert-butyldimethylsilyl)oxy)phenyl)-2,3-dihydroxypropanoate (16)}

Methyl caffeate $(\mathbf{1 5}, 2.30 \mathrm{~g}, 5.43 \mathrm{mmol})$ dissolved in tert-butyl alcohol $(20 \mathrm{~mL})$ was added to a suspension of $\mathrm{K}_{2} \mathrm{OsO}_{4}(2.80 \mathrm{~g}, 7.60 \mathrm{mmol}), \mathrm{K}_{3}\left[\mathrm{Fe}(\mathrm{CN})_{6}\right](2.50 \mathrm{~g}, 7.60 \mathrm{mmol}), \mathrm{K}_{2} \mathrm{CO}_{3}(1.05 \mathrm{~g}, 7.60 \mathrm{mmol})$ and methanesulfonamide $(10 \mathrm{mmol})$ in tert-butyl alcohol $(40 \mathrm{~mL})$ under a nitrogen atmosphere at $0{ }^{\circ} \mathrm{C}$. The mixture was stirred for $28 \mathrm{~h}$ until 15 was completely consumed. The reaction was quenched with a saturated solution of sodium sulfite. The mixture was allowed to warm up to room temperature and stirred for $1 \mathrm{~h}$. The reaction mixture was extracted with $\mathrm{CH}_{2} \mathrm{Cl}_{2}(100 \mathrm{~mL} \times 3)$ and the combined organic layers washed with brine, dried over anhydrous sodium sulfate, filtered and concentrated in vacuo. The resulting residue was purified by silica gel chromatography to give dihydroxyl ester $16(2.10 \mathrm{~g}, 85 \%)$ as a white solid. ${ }^{1} \mathrm{H}-\mathrm{NMR}\left(\mathrm{CDCl}_{3}\right): \delta 6.91(\mathrm{~s}, 1 \mathrm{H}), 6.81(\mathrm{~s}, 2 \mathrm{H}), 4.85(\mathrm{~s}, 1 \mathrm{H}), 4.30(\mathrm{~s}$, $1 \mathrm{H}), 3.77(\mathrm{~s}, 3 \mathrm{H}), 3.12(\mathrm{~s}, 1 \mathrm{H}), 2.70(\mathrm{~s}, 1 \mathrm{H}), 0.99(\mathrm{~s}, 9 \mathrm{H}), 0.98(\mathrm{~s}, 9 \mathrm{H}), 0.19(\mathrm{~s}, 6 \mathrm{H}), 0.19(\mathrm{~s}, 6 \mathrm{H}) ;{ }^{13} \mathrm{C}-\mathrm{NMR}$ $\left(\mathrm{CDCl}_{3}\right): \delta 173.2,146.8,146.8,133.0,120.8,119.5,119.4,74.9,74.3,52.6,25.9,18.4,18.4,-4.1,-4.1$.

\subsection{Methyl 3-(3,4-bis((tert-butyldimethylsilyl)oxy)phenyl)-2-hydroxypropanoate (17)}

$\mathrm{Et}_{3} \mathrm{SiH}(7.78 \mathrm{~mL}, 48.83 \mathrm{mmol})$ and trifluoroacetic acid $(7.26 \mathrm{~mL}, 97.7 \mathrm{mmol})$ were added to a solution of dihydroxyl ester $16(4.46 \mathrm{~g}, 9.77 \mathrm{mmol})$ dissolved in dry $\mathrm{CH}_{2} \mathrm{Cl}_{2}(40 \mathrm{~mL})$ at $0{ }^{\circ} \mathrm{C}$. The reaction mixture was allowed to warm up to room temperature and stirred for $10 \mathrm{~h}$. The reaction was quenched with a saturated aqueous solution of sodium bicarbonate and extracted with $\mathrm{CH}_{2} \mathrm{Cl}_{2}(80 \mathrm{~mL} \times 3)$. The combined organic layers were washed with brine, dried over anhydrous sodium sulfate, filtered and concentrated in vacuo. The resulting residue was purified by silica gel chromatography to give the monohydroxy product $17(3.70 \mathrm{~g}, 86 \%)$ as a white semi-solid. ${ }^{1} \mathrm{H}-\mathrm{NMR}\left(\mathrm{CDCl}_{3}\right): \delta 6.76(\mathrm{~d}, J=8.0 \mathrm{~Hz}$, $1 \mathrm{H}), 6.75(\mathrm{~s}, 1 \mathrm{H}), 6.66(\mathrm{~d}, J=8.0 \mathrm{~Hz}, 1 \mathrm{H}), 4.41(\mathrm{br} \mathrm{s}, 1 \mathrm{H}), 3.74(\mathrm{~s}, 3 \mathrm{H}), 3.00(\mathrm{dd}, J=4.4$ and $14.0 \mathrm{~Hz}, 1 \mathrm{H})$, 2.89 (br s, $1 \mathrm{H}), 2.88(\mathrm{dd}, J=6.4$ and $14.0 \mathrm{~Hz}, 1 \mathrm{H}), 1.01(\mathrm{~s}, 18 \mathrm{H}), 0.21(\mathrm{~s}, 12 \mathrm{H}) . ;{ }^{13} \mathrm{C}-\mathrm{NMR}\left(\mathrm{CDCl}_{3}\right): \delta$ $174.5,146.6,145.8,129.3,122.5,122.4,120.9,71.4,52.2,39.9,26.0,18.4,-4.1$. 
3.14. Methyl 3-(3,4-bis((tert-butyldimethylsilyl)oxy)phenyl)-2-(2-(dimethoxyphosphoryl)acetoxy)-propanoate (3)

Dicyclohexylcarbodiimide (DCC, $2.58 \mathrm{~g}, 12.49 \mathrm{mmol}$ ) and a catalytic amount of 4-dimethylaminopyridine $(0.19 \mathrm{~g}, 1.56 \mathrm{mmol})$ were added to a solution of the monohydroxy product $17(3.44 \mathrm{~g}, 7.81 \mathrm{mmol})$ and 2-(dimethoxyphosphoryl)acetic acid $18(2.10 \mathrm{~g}, 12.49 \mathrm{mmol})$ in dry $\mathrm{CH}_{2} \mathrm{Cl}_{2}(40 \mathrm{~mL})$ at $0{ }^{\circ} \mathrm{C}$ under a nitrogen atmosphere, and the resulting mixture was then stirred for $1 \mathrm{~h}$. The reaction was quenched with brine, extracted with $\mathrm{CH}_{2} \mathrm{Cl}_{2}(50 \mathrm{~mL} \times 3)$ and the combined organic layers dried over anhydrous sodium sulfate, filtered and concentrated in vacuo. The resulting residue was purified by silica gel chromatography to give compound $3(4.15 \mathrm{~g}, 90 \%)$ as a white semi-solid. ${ }^{1} \mathrm{H}-\mathrm{NMR}\left(\mathrm{CDCl}_{3}\right): \delta 6.69(\mathrm{~d}, J=8.0 \mathrm{~Hz}, 1 \mathrm{H}), 6.64(\mathrm{~s}, 1 \mathrm{H}), 6.60(\mathrm{~d}, J=8.4 \mathrm{~Hz}, 1 \mathrm{H})$, $5.15(\mathrm{dd}, J=4.8$ and $7.2 \mathrm{~Hz}, 1 \mathrm{H}), 3.72(\mathrm{~d}, J=11.2 \mathrm{~Hz}, 3 \mathrm{H}), 3.70(\mathrm{~d}, J=11.2 \mathrm{~Hz}, 3 \mathrm{H}), 3.64(\mathrm{~s}, 3 \mathrm{H}), 2.97$ $(\mathrm{d}, J=21.6 \mathrm{~Hz}, 2 \mathrm{H}), 2.94-3.00(\mathrm{~m}, 2 \mathrm{H}), 0.93(\mathrm{~s}, 9 \mathrm{H}), 0.92(\mathrm{~s}, 9 \mathrm{H}), 0.14(\mathrm{~s}, 6 \mathrm{H}), 0.13(\mathrm{~s}, 6 \mathrm{H}) . ;{ }^{13} \mathrm{C}-\mathrm{NMR}$ $\left(\mathrm{CDCl}_{3}\right): \delta 169.4,165.1(\mathrm{~d}, J=4.7 \mathrm{~Hz}), 146.7,146.0,128.4,122.2,122.2,120.9,74.1,53.2,52.2,36.6,32.9$ $(\mathrm{d}, J=135.0 \mathrm{~Hz}), 25.9,18.4,18.4,-4.1$; HRMS (TOF-MS): $m / z$ calcd for $\mathrm{C}_{26} \mathrm{H}_{47} \mathrm{O}_{9} \mathrm{PSi}_{2} \mathrm{Na}[\mathrm{M}+\mathrm{Na}]^{+}$ 613.2388. Found 613.2386.

\subsection{2-(3,4-Bis(tert-butyldimethylsilyloxy)phenyl-1-methoxycarbonyl)ethyl(E)-3-((E)-2,3,3', $4^{\prime}$-tetrakis(tert -butyldimethylsilyloxy)stylben-6-yl)acrylate (19)}

$\mathrm{NaH}$ (30.9 mg, $0.77 \mathrm{mmol}, 60 \%$ in mineral oil) was added to a solution of $3(0.453 \mathrm{~g}, 0.77 \mathrm{mmol})$ in dry THF $(4 \mathrm{~mL})$ at $0{ }^{\circ} \mathrm{C}$ under a nitrogen atmosphere and the reaction mixture stirred for $30 \mathrm{~min}$. Aldehyde $2(0.427 \mathrm{~g}, 0.59 \mathrm{mmol})$ dissolved in dry THF $(1.0 \mathrm{~mL})$ was added slowly to the mixture and stirred for another $3 \mathrm{~h}$ at $0{ }^{\circ} \mathrm{C}$. The reaction was quenched with a saturated aqueous solution of ammonium chloride, extracted with ethyl acetate $(10 \mathrm{~mL} \times 3)$ and the combined organic layers dried over anhydrous sodium sulfate, filtered and concentrated in vacuo. The resulting residue purified by silica gel chromatography to give compound $19(0.60 \mathrm{~g}, 65 \%, E: \mathrm{Z}=77: 23)$ as a yellow oil. ${ }^{1} \mathrm{H}$ - NMR $\left(\mathrm{CDCl}_{3}\right): \delta 8.04(\mathrm{~d}, J=15.6 \mathrm{~Hz}, 1 \mathrm{H}), 7.18(\mathrm{~d}, J=8.0 \mathrm{~Hz}, 1 \mathrm{H}), 7.01(\mathrm{~d}, J=16.0 \mathrm{~Hz}, 1 \mathrm{H}), 6.99(\mathrm{~s}, 1 \mathrm{H}), 6.96(\mathrm{~d}$, $J=8.8 \mathrm{~Hz}, 1 \mathrm{H}), 6.81(\mathrm{~d}, J=8.4 \mathrm{~Hz}, 1 \mathrm{H}), 6.73(\mathrm{~s}, 1 \mathrm{H}), 6.72(\mathrm{~d}, J=8.8 \mathrm{~Hz}, 1 \mathrm{H}), 6.63(\mathrm{~d}, J=7.2 \mathrm{~Hz}, 1 \mathrm{H}), 6.45$ $(\mathrm{d}, J=16.8 \mathrm{~Hz}, 1 \mathrm{H}), 6.32(\mathrm{~d}, J=15.6 \mathrm{~Hz}, 1 \mathrm{H}), 5.25(\mathrm{br} \mathrm{s}, 1 \mathrm{H}), 3.69(\mathrm{~s}, 3 \mathrm{H}), 2.97-3.08(\mathrm{~m}, 2 \mathrm{H}), 1.06(\mathrm{~s}, 18 \mathrm{H})$, $0.98(\mathrm{~s}, 18 \mathrm{H}), 0.96(\mathrm{~s}, 18 \mathrm{H}), 0.28(\mathrm{~s}, 6 \mathrm{H}), 0.23(\mathrm{~s}, 12 \mathrm{H}), 0.19(\mathrm{~s}, 12 \mathrm{H}), 0.11(\mathrm{~s}, 6 \mathrm{H}) . ;{ }^{13} \mathrm{C}-\mathrm{NMR}\left(\mathrm{CDCl}_{3}\right): \delta$ 169.9, 165.9, 148.3, 146.6, 146.4, 146.1, 145.5, 145.3, 144.2, 136.7, 133.0, 130.7, 128.6, 126.5, 121.9, 121.7, 121.1, 120.6, 120.4, 119.9, 119.1, 118.7, 115.0, 72.6, 51.6, 36.4, 25.7, 25.5, 25.5, 18.3, 18.0, 17.9, -3.8, -4.0, $-4.0,-4.5$; HRMS (TOF-MS): $m / z$ calcd for $\mathrm{C}_{63} \mathrm{H}_{108} \mathrm{O}_{10} \mathrm{Si}_{6} \mathrm{Na}[\mathrm{M}+\mathrm{Na}]^{+} 1215.6450$. Found 1215.6457.

3.16. 3-(3,4-Dihydroxyphenyl)-1-methoxy-1-oxopropan-2-y(E)-3-(2-((E)-3,4-dihydroxystyryl)-3,4dihydroxyphenyl)acrylate (1)

$\mathrm{Et}_{3} \mathrm{~N} \bullet 3 \mathrm{HF}(0.81 \mathrm{~g}, 5.02 \mathrm{mmol})$ was added to a solution of $19(0.50 \mathrm{~g}, 0.42 \mathrm{mmol})$ in dry pyridine $(4 \mathrm{~mL})$ at $0{ }^{\circ} \mathrm{C}$ under a nitrogen atmosphere. The reaction mixture was stirred for $1 \mathrm{~h}$ and then diluted with methanol. The mixture was extracted with $\mathrm{CH}_{2} \mathrm{Cl}_{2}(10 \mathrm{~mL} \times 3)$ and the combined organic layers washed with brine, dried over anhydrous sodium sulfate, filtered and concentrated in vacuo. The resulting residue was purified by silica gel chromatography to give $( \pm)$-methyl salvianolate $\mathrm{A}(\mathbf{1}$, $0.196 \mathrm{~g}, 92 \%)$ as a yellow solid. ${ }^{1} \mathrm{H}-\mathrm{NMR}\left(\mathrm{CD}_{3} \mathrm{OD}\right): \delta 8.00(\mathrm{~d}, J=16.0 \mathrm{~Hz}, 1 \mathrm{H}), 7.07(\mathrm{~d}, J=16.4 \mathrm{~Hz}, 1 \mathrm{H})$, $7.05(\mathrm{~d}, J=8.0 \mathrm{~Hz}, 1 \mathrm{H}), 6.98(\mathrm{~s}, 1 \mathrm{H}), 6.81(\mathrm{~d}, J=7.2 \mathrm{~Hz}, 1 \mathrm{H}), 6.69(\mathrm{~d}, J=8.0 \mathrm{~Hz}, 1 \mathrm{H}), 6.68(\mathrm{~d}, J=8.4 \mathrm{~Hz}$, $1 \mathrm{H}), 6.58(\mathrm{~s}, 1 \mathrm{H}), 6.57(\mathrm{~d}, J=7.6 \mathrm{~Hz}, 1 \mathrm{H}), 6.56(\mathrm{~d}, J=16.0 \mathrm{~Hz}, 1 \mathrm{H}), 6.44(\mathrm{~d}, J=8.0 \mathrm{~Hz}, 1 \mathrm{H}), 6.21(\mathrm{~d}$, $J=16.0 \mathrm{~Hz}, 1 \mathrm{H}), 5.11(\mathrm{dd}, J=5.2$ and $7.2 \mathrm{~Hz}, 1 \mathrm{H}), 3.61(\mathrm{~s}, 3 \mathrm{H}), 2.89-2.94(\mathrm{~m}, 1 \mathrm{H}) . ;{ }^{13} \mathrm{C}-\mathrm{NMR}\left(\mathrm{CD}_{3} \mathrm{OD}\right): \delta$ 170.8, 167.1, 146.9, 146.2, 145.3, 145.1, 144.7, 143.9, 143.0, 136.5, 130.0, 127.4, 127.1, 124.7, 120.6, 119.3, 119.0, 118.7, 116.0, 115.1, 115.0, 113.9, 113.5, 112.7, 73.3, 51.3, 36.5; HRMS (TOF-MS): $m / z$ calcd for $\mathrm{C}_{27} \mathrm{H}_{24} \mathrm{O}_{10} \mathrm{Na}[\mathrm{M}+\mathrm{Na}]^{+}$531.1262. Found 531.1262.

\section{Conclusions}

We have accomplished the first total synthesis of the polyphenol natural product, $( \pm)$-methyl salvianolate A, using a convergent approach. The key features of the approach are the 
Horner-Wadsworth-Emmons reaction and the protection of multiple hydroxyl groups using silyl protecting groups, which avoid the side reactions often observed during the deprotection step. Employment of the readily removable silyl protecting group in the present approach is a practicable route to methyl salvianolate A and its derivatives. Further studies on the application of this approach to natural products containing polyphenol units are in progress and will be disclosed in due course.

Supplementary Materials: NMR spectra for all synthetic compounds are available online.

Author Contributions: S.H. and X.W. conceived and designed the experiments; B.W. and L.W. performed the experiments; Y.P. (Ying Peng), Y.P. (Yiying Pang) and H.X. analyzed the data and contributed reagents; S.H. and X.W. wrote the manuscript.

Funding: This research was funded by the National Science Foundation of China, grant number 21062088 and 21562020; Science and Technology Plan Project of Jiangxi Province, grant number 20151BBG70028 and 20142BBE50006.

Acknowledgments: We thank the National Science Foundation of China $(21062088,21562020)$ and Science and Technology Plan Project of Jiangxi Province (No. 20151BBG70028, 20142BBE50006) for funding support.

Conflicts of Interest: The authors declare no conflict of interest.

\section{References}

1. Chinese Pharmacopoeia Commission. Pharmacopoeia of the People's Republic of China; China Medical Science Press: Beijing, China, 2015; Volume 1, p. 76.

2. Li, L.N.; Tan, R.; Chen, W.M. Salvianolic acid A: A new depside from roots of Salvia miltiorrhiza. Planta Med. 1984, 50, 227-228.

3. Liu, G.T.; Zhang, T.M.; Wang, B.E.; Wang, Y.W. Protective action of seven natural phenolic compounds against peroxidative damage to biomembranes. Biochem. Pharmacol. 1992, 43, 147-152. [CrossRef]

4. Lin, T.J.; Zhang, K.J.; Liu, G.T. Effects of salvianolic acid a on oxygen radicals released by rat neutrophils and on neutrophil function. Biochem. Pharmacol. 1996, 51, 1237-1241. [CrossRef]

5. Wang, X.J.; Wang, Z.B.; Xu, J.X. Effect of salvianic acid A on lipid peroxidation and membrane permeability in mitochondria. J. Ethnopharmacol. 2005, 97, 441-445. [CrossRef] [PubMed]

6. Tsai, M.K.; Lin, Y.T.; Huang, Y.L. Effects of salvianolic acids on oxidative stress and hepatic fibrosis in rats. Toxicol. Appl. Pharmacol. 2010, 242, 155-164. [CrossRef] [PubMed]

7. Wang, S.B.; Tian, S.; Yang, F.; Du, G.H. Cardioprotective effect of salvianolic acid A on isoproterenol-induced myocardial infarction in rats. Eur. J. Pharmacol. 2009, 615, 125-132. [CrossRef] [PubMed]

8. Jiang, B.H.; Li, D.F.; Deng, Y.P.; Teng, F.K.; Chen, J.; Xue, S.; Kong, X.Q.; Luo, C.; Shen, X.; Jiang, H.L.; et al. Salvianolic acid A, a novel matrix metalloproteinase-9 inhibitor, prevents cardiac remodeling in spontaneously hypertensive rats. PLoS ONE 2013, 8, e59621. [CrossRef] [PubMed]

9. Fan, H.-Y.; Fu, F.-H.; Yang, M.-Y.; Xu, H.; Zhang, A.-H.; Liu, K. Antiplatelet and antithrombotic activities of salvianolic acid A. Thromb. Res. 2010, 126, e17-e22. [CrossRef] [PubMed]

10. Zheng, X.W.; Chen, S.Y.; Yang, Q.T.; Cai, J.X.; Zhang, W.P.; You, H.S.; Xing, J.F.; Dong, Y.L. Salvianolic acid A reverses the paclitaxel resistance and inhibits the migration and invasion abilities of human breast cancer cells by inactivating transgelin 2. Cancer Biol. Ther. 2015, 16, 1407-1414. [CrossRef] [PubMed]

11. Zhang, Z.-F.; Peng, Z.-G.; Gao, L.; Dong, B.; Li, J.-R.; Li, Z.-Y.; Chen, H.-S. Three new derivatives of anti-HIV-1 polyphenols isolated from Salvia yunnanensis. J. Asian Nat. Prod. Res. 2008, 10, 391-396. [CrossRef] [PubMed]

12. Kan, S.D.; Chen, Z.Z.; Shao, L.; Li, J.-A. Transformation of salvianolic acid $b$ to salvianolic acid A in aqueous solution and the in vitro liver protective effect of the main products. J. Food Sci. 2014, 79, 499-504. [CrossRef] [PubMed]

13. Chen, W.Q.; Zhou, H.G.; Li, J.N.; Sun, B. Synthetic Method for Salvianolic Acid A. CN Patent 105085267A, 2015.

14. Zheng, Y.; Song, W.-B.; Xuan, L.-J. The asymmetric total synthesis of ( $\mathrm{t}$ )-salvianolic acid A. Tetrahedron 2016, 72, 5047-5050. [CrossRef]

15. Xu, K.; Liu, H.; Liu, D.L.; Sheng, C.; Shen, J.F.; Zhang, W.B. Synthesis of (+)-salvianolic acid A from sodium Danshensu. Tetrahedron 2018, 74, 5996-6002. [CrossRef]

16. Dalla, V.; Cotelle, P. The total synthesis of salvianolic acid F. Tetrahedron 1999, 55, 6923-6930. [CrossRef] 
17. Huang, S.P.; Wang, J.W.; Wang, L.P.; Xu, T.X.; Li, X.T.; Len, X.; Wang, X.J. Method for Synthesizing Natural Product Salvianolic Acid A Methyl Ester. CN Patent 106905154A, 2017.

18. Hwu, J.R.; Varadaraju, T.G.; Abd-Elazem, I.S.; Huang, R.C.-C. First total syntheses of oresbiusins A and B, their antipodes, and racemates: Configuration revision and anti-HIV activity. Eur. J. Org. Chem. 2012, 25, 4684-4688. [CrossRef]

19. Jiang, Z.-Y.; Wang, Y.-G. A mild, efficient and selective deprotection of t-butyldimethylsilyl-protected phenols using cesium carbonate. Tetrahedron Lett. 2003, 44, 3859-3861. [CrossRef]

20. Ankala, S.V.; Fenteany, G. Selective deprotection of either alkyl or aryl silyl ethers from aryl, alkyl bis-silyl ethers. Tetrahedron Lett. 2002, 43, 4729-4732. [CrossRef]

21. Crouch, R.D.; Stieff, M.; Frie, J.L.; Cadwallader, A.B.; Bevis, D.C. Selective Deprotection of Silyl-Protected Phenols Using Solid NaOH and a Phase Transfer Catalyst. Tetrahedron Lett. 1999, 40, 3133-3136. [CrossRef]

22. Duynstee, H.I.; de Koning, M.C.; Ovaa, H.; van der Marel, G.A.; van Boom, J.H. Synthesis of verbascoside: A dihydroxyphenylethyl glycoside with diverse bioactivity. Eur. J. Org. Chem. 1999, 10, 2623-2632. [CrossRef]

Sample Availability: Samples are not available from the authors. 